\title{
毛髪のパーマネントウェーブ形成におよぼす前処理の効果
}

\author{
天谷美奈子*1,*, 澤田＼cjkstart学*1, 吉田 治彦*1, 上甲 恭平*2
}

\section{Effect of the Pretreatment to Permanent Wave Formation of Hair}

\author{
${\text { Minako Amaya }{ }^{* 1, *}, \text { Manabu Sawada }}^{* 1}$, Haruhiko Yoshida ${ }^{* 1}$, and Kyohei Joko ${ }^{* 2}$
}

${ }^{* 1}$ NICCA CHEMICAL CO.,LTD., 4-23-1, Bunkyo, Fukui-city, Fukui 910-8670, Japan

${ }^{*}$ Sugiyama Jogakuen University, 17-3, Hoshigaoka-motomachi, Chikusa-ku, Nagoya, Aichi 464-8662, Japan

\begin{abstract}
The effect of the modification of human hair components on the permanent wave set of a human hair was investigated by analyzing the wave performance for both normal hairs and pretreatment hairs. Pretreatments carried out by treating the normal hairs with formic acid and acetic acid, ethanol/ chloroform, and boiling water. The difference between the protein chain rearrangements to equilibrium the curled configuration of normal and pretreatment hairs were observed during drying of the waved hairs. Specifically, the hair samplers pretreated with formic acid and acetic acid or ethanol/chloroform have made it difficult to maintain the waving performance in wet state. These results suggest that the constituent components of CMC play an important role to equilibrium the curled configuration by effectively operating as an adhesion component between the cells. A role of the constituent components of CMC for bleached hairs is also discussed.
\end{abstract}

(Received 12 January, 2012; Accepted 10 August, 2012)

\section{1. 緒 言}

毛髪は, 毛髪の最外層にうろこ状に並んでいるキュー ティクル細胞, 毛髪内部の大部分を占める紡錘状のコル テックス細胞で構成されている.これらの細胞は, 細胞 膜複合体 (Cell Membrane Complex; CMC) と呼ばれる細胞 組織により接着されている。 また, キューティクル細胞 間に存在する CMC と, コルテックス細胞層で網目状の模 様を形成して存在する CMC は組織の構成が異なることが 報告されている $[1]$.

毛髪のパーマネントウェーブ処理は, 美容的な外観を 付与するために毛髪内の化学的構造変化を利用して施術 される. 毛髪をロッドに巻いておいた状態で還元・酸化 反応を行い, 毛髪内の構造変化によりウェーブを形成さ せる方法が一般的である。第一段階で，還元剤を用いて 毛髪内のジスルフィド結合を切断し，第二段階で酸化剂 を用いて切断されたジスルフィド結合を再結合させる方 法を経る[2].

還元剤が作用した組織成分域(還元領域)では, 自由度 が高まったケラチン分子鎖がロッドの巻きで生じた歪み (初期歪み) を解消するように再配列すると考えられてい

\footnotetext{
\# corresponding author

*1 日華化学株式会社

*2 椙山女学園大学
}

る. 言い換えると, 一連のウェーブ処理により得られた ウェーブ形状は, 初期歪みが解消され新たな構造を保持 しょうとする還元領域と歪みが解消されず元の形状へ戻 ろうとする非還元領域のバランスによって形成されてい ると言える.ただしこの時, いずれの領域においても水 素結合やイオン結合の二次結合の切断/再架橋により初期 歪みの一部は緩和されている. そのため非還元領域も二 次結合の切断/再架橋による構成分子鎖の再配列が生じて いると考えなければならない.

パーマネントウェーブ処理により最終的に形成される ウェーブは, ウェーブ処理後のロッドから外した時点で 発生する非還元領域の元の状態に戻ろうとする復元力に よって, ロッドの巻き回数に相当するウェーブ山数より も少ない山数を持つウェーブとなる.この場合, キュー ティクルやコルテックスを含む還元領域の構成分子鎖は 非還元領域の復元力により生じた歪みを解消すべく再々 配列するものと考えられる。

以上のように，ウェーブ形成には歪み緩和のために毛 髪分子構造変化が不可欠であり, この変化が起こる主た る組織および部位に関して数多く研究されてきたが, 未 だ明確な結論は得られていない。これまでの主な議論で は, コルテックス細胞内での構造変化, 特にマトリック ス (中間系結合タンパク : IFAP)や中間フィラメント (IF)/ IFAP 構造での変化に関心が寄せられたものが多く, 他の 細胞組織であるキューティクル細胞や CMC などの非ケラ 
チンタンパク組織の寄与や役割についてはほとんど議論 されていない. F. J. Wortmann らはキューティクル細胞が 毛髪繊維の還元率を減少させているとともに, キューティ クルそのものの剛性のためにウェーブ形成に重要な役割 を果たしていると述べている[3]. また，C. R. Robbins は 彼の著書でこれまでの報文を引用するなかでパーマネン トのウェーブ保持力はコルテックス細胞内での再配列後 の IF/IFAP 間相互作用だけで考えていたのでは説明できず, キューティクル細胞内での構成分子間相互作用が涑く関 与しているとの推測ができると述べている $[4]$.

我々もまた, コルテックス細胞以外の構成組織の中で も非ケラチンタンパク組織に着目し，ウェーブ形成に及 ぼす非ケラチンタンパク組織の役割を明らかにすること を目的とした，本報告では， CMCを含む構成成分の抽出 および構造変化をもたらすことが知られているギ酸・酢 酸処理 $[5]$, およびエタノール/クロロホルム処理 $[6,7]$ を パーマネントウェーブ処理の前処理として実施した。一 方で, CMCへの影響は少ないが非ケラチンタンパク質の 抽出が確認されている煮沸処理 $[8]$ を比較として選択し, これらの前処理を施した毛束のパーマネントウェーブ形 状を観察した。 また，毛髪構造に影響を及ぼすとされて いるブリーチ処理毛髪についても同様の検討を行い, 前 処理の効果をパーマネントウェーブ形状観察により比較 した.

\section{2. 実 験}

\section{1 試薬}

試薬には, $98 \%$ ギ酸, $99 \%$ 酢酸, $99 \%$ クロロホルム, $100 \%$ エタノール, チオグリコール酸アンモニウム水溶液(チオ グリコール酸含有 50\%), 臭素酸ナトリウム, $28 \%$ アンモ ニア水, リン酸水素二ナトリウム, リン酸二水素ナトリ ウム, 12Lv ライトナー(DEMI, ASSORT ALLIA 12/LT), ブリーチパウダー(DEMI, BLEACH POWDER), 過酸化 水素 $6 \%$ 溶液 (DEMI, ASSORT ALLIA Ox-6.0)を用いた。

\section{2 試料毛の調製}

毛髪試料は, カラーリングやパーマネントウェーブ処 理などを施していない日本人女子の同一人 (12 歳)の毛髪 を使用した。長さ $20 \mathrm{~cm}$, 重さ $0.5 \mathrm{~g}$ の毛束を作製し， $1 \%$ ラウリル硫酸ナトリウム (エデト酸二ナトリウム $0.1 \%$ 含 有)に 1 時間浸漬し, その後水洗して風乾し, 試料毛束を 調製した. 以下, この状態の毛髪を未処理毛と称す。

\subsection{1 ブリーチ処理}

ブリーチ処理は, $12 \mathrm{Lv}$ ライトナー, ブリーチパウダー と過酸化水素 6\% 溶液を $1: 1: 4$ で混合したものを使用し 毛束に対し 2 倍重量を塗布後, $32^{\circ} \mathrm{C}$ で 30 分間放置した. その後, 毛束を充分に洗浄し風乾した.

\section{3 毛髮前処理}

試料毛束に対し, 毛髪構成成分を除去する目的で, 以 下に示す各種毛髪前処理を行い, 各処理毛束を調製した.
各種毛髪前処理条件は, 文献 $[5-8]$ を参考にした.

\subsection{1 ギ酸・酢酸処理}

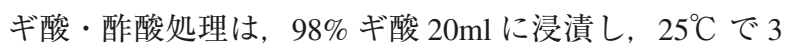
時間放置後, 蒸留水で十分に洗浄し風乾を行った。その 後, $3 \%$ 酢酸 $20 \mathrm{ml}$ に浸漬し, $25^{\circ} \mathrm{C}$ で 3 時間放置した後, 蒸留水で十分に洗浄し風乾を行った.

\subsection{2 エタノール／クロロホルム処理}

溶媒処理は, $30 \%$ エタノール含有クロロホルム溶液 $20 \mathrm{ml}$ に浸漬し, $25^{\circ} \mathrm{C}$ で 5 時間放置後, 蒸留水で十分に洗 浄し風乾を行った。

\subsection{3 煮沸処理}

煮沸処理は, 蒸留水 $20 \mathrm{ml}$ に浸漬し, $100^{\circ} \mathrm{C}$ で 30 分放置 後, 蒸留水で十分に洗浄し風乾した.

\section{4 パーマネントウェーブ処理}

還元処理溶液は 7\% のチオグリコール酸水溶液を作製し, アンモニア水溶液を用いて pH9.0に調整した. 酸化処理 溶液は $7 \%$ ブロム酸水溶液を作製し, リン酸水素二ナトリ ウム, リン酸二水素ナトリウムを用いて pH6.0に調整し た。

未処理毛にギ酸・酢酸処理, エタノール/クロロホルム 処理, 煮沸処理を行った毛束のパーマネントウェーブ処 理には， $15 \mathrm{~mm}$ 径ロッドを使用した，さらに，ブリーチ処 理毛にギ酸・酢酸処理, エタノール/クロロホルム処理, 煮沸処理を行った毛束のパーマネントウェーブ処理には, $12 \mathrm{~mm}$ 径ロッドを使用した. 基準となる未処理毛, ブリー チ毛へのパーマネントウェーブ処理には, $12 \mathrm{~mm}$ 径ロッド と $15 \mathrm{~mm}$ 径ロッドの両方を使用した.

パーマネントウェーブ処理は, 上記前処理をした毛束 をロッドに平巻きで巻き, 毛髪重量に対して 6 倍となる ように還元処理溶液を塗布し, 室温で 15 分放置した。 そ の後充分に水洗した後に酸化処理溶液を毛髪重量に対し て 6 倍となるように塗布し, 室温で 10 分放置した。 その 後, 充分に水洗しロッドを外して風乾した。

\section{5 ウェーブ形状の比較}

ウェーブ形状の比較は, ロッドを外した直後の湿潤状

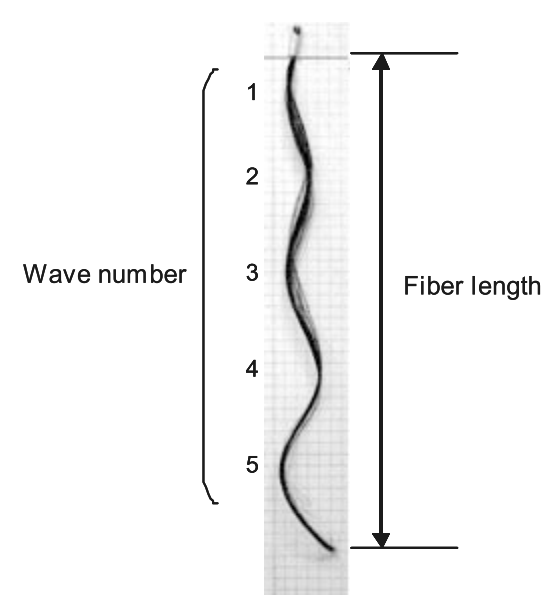

Fig. 1 Fiber length and wave number on a permanent waving performance. 
態と風乾後の乾燥状態のウェーブ毛の毛髪長, 山数を目 視により評価した。評価基準については, 図 1 に示す ウェーブ形状モデルに従った。

\section{3. 結果と考察}

\section{1 未処理毛髮でのウェーブ形成}

まず，未処理毛髪に対する $12 \mathrm{~mm}$ 径および $15 \mathrm{~mm}$ 径の ロッドを用いたパーマネントウェーブ処理後のウェーブ 形状を検討し, その結果を図 2 に示した。 図中のウェー ブは，使用ロッドに応じた形状が得られており，正常な ウェーブ形状であると言えるが, 乾燥によるウェーブ形 状の変化がロッド径の違いにより異なることが分かる.

$15 \mathrm{~mm}$ 径のロッドを使用したウェーブ毛髪では, 乾燥後の ウェーブ形状が湿潤時の形状とほとんど変化がなかった のに対して，12mm 径のロッドを使用したウェーブ毛髪で は, 乾燥することによりウェーブ山数が 1 山減少し, 毛 髮長も大きく伸びている.

通常, ウェーブ処理後, 毛髪束をロッドより外し湿潤 状態でボードに吊るした場合, 毛髪には自重による応力 がかかる，この場合，この自重応力に対抗できない一部 の構成分子は応力を緩和するように再配列する。ささらに 乾燥時の脱膨潤に伴う応力が発生するが, この応力に対 しても, その応力を緩和するために構成分子の再配列が 起こる. 一般的には, 乾燥ウェーブ毛髪では湿潤ウェー
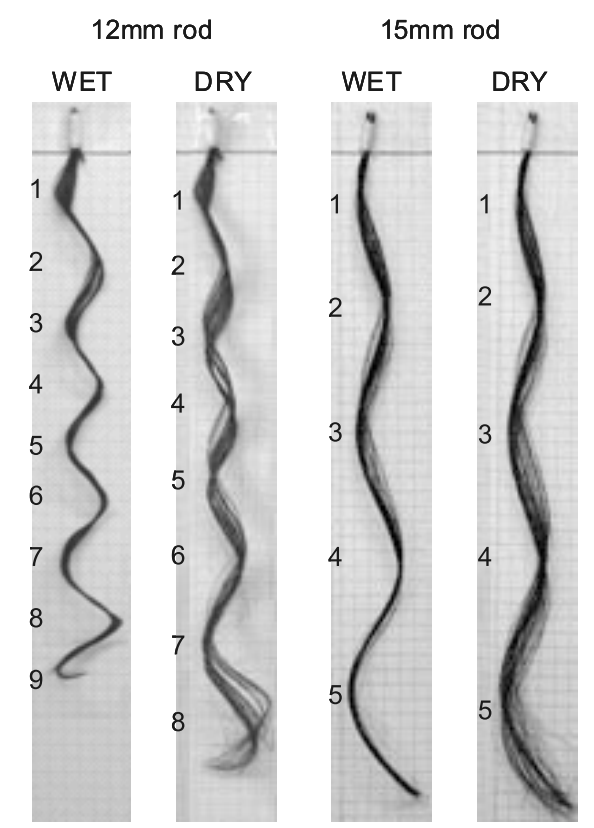

Fig. 2 The waving performance of normal hair fibers waved by the permanent waving process consisting in using two rod types of $12 \mathrm{~mm}$ and $15 \mathrm{~mm}$ and reducing with $7 \%$ thioglycolic acid (TGA) solution at $\mathrm{pH} 9.0$, room temperature (RT) for $15 \mathrm{~min}$, rinsing with water and oxidizing with $7 \%$ sodium bromate (SB) solution $\mathrm{pH}$ 6.0, RT for $10 \mathrm{~min}$. [WET : in the wet state, DRY : in the dry state.]
ブ毛髪に比べ，毛髪長が伸びウェーブ径が大きくなった ウェーブ状態となることは, 美容サロン等ではよく知ら れている. すなわち, 図 2 の結果は, 同一毛髪試料であっ てもウェーブ径(ロッドに依存している)によって形成し た分子構造は, 自重応力および脱膨潤応力に対する抵抗 力が異なる構造であることを意味している.

ところで, 適正に酸化処理されたウェーブ毛髪では, 自重応力および脱膨潤応力の緩和は一次結合であるジス ルフィド結合の切断/再結合の関与はほとんどないと考え られ, 水素結合やイオン結合の二次結合の切断/再結合に 依存するものと考えられる。この考えに従えば, $15 \mathrm{~mm}$ 径 で形成したウェーブ毛髪の構成分子構造は, これらの応 力に対抗しうる構造であるか, 二次結合の切断を伴うこ となく構成分子構造の再配列で緩和する構造であると考 えられる。それに対して，12mm 径で形成したウェーブ毛 髪の分子構造は, 二次結合を切断/再結合しなければ応力 を緩和することができない構造であると考えられる．

このことから, ロッドから外した後の水洗過程および 乾燥過程で毛髪にかかる歪み応力の緩和メカニズムは一 律ではなく, ウェーブ処理により再配列した構成分子構 造に依存すると考えられ, その分子の再々配列による分 子構造がウェーブ形状を保持していると言える.

\section{2 前処理毛髮でのウェーブ形成}

\subsection{1 前処理による毛髮構成成分の抽出量}

各前処理後, 抽出物は回収し重量\%を求めた。 その結 果, ギ酸・酢酸処理では 5.0\%, エ夕ノールノクロホルム 処理では $0.3 \%$, 煮沸処理では $0.3 \%$ の抽出物が得られ, いずれの処理によっても毛髪繊維内部に何らかの影響を もたらしていると予想される.

\subsection{2 ウェーブ形状に及ぼす前処理の影響}

図 3 は未処理毛髪にギ酸・酢酸処理, エ夕ノール/クロ ロホルム処理および煮沸処理を行った前処理毛髪での パーマネントウェーブ処理後のウェーブ毛髪の形状を示 したものである.

未処理毛髪のウェーブ形状 (図 3(1)-WET) と比べ前処理 毛髪のウェーブ形状 (図 3(2)〜 (4)-WET) は, 湿潤状態で いずれもウェーブ山数が 1 山増え, 毛髪長も短くなって いた. 通常, 適正なウェーブ処理では S-S 結合の切断量 の増加とともにより強いウェーブ(ウェーブ山数が増加し, 毛髪長も短くなる) が形成されることは既知の事実である. このことからすれば, ここで用いた前処理はいずれも還 元剤の浸透経路に関する毛髪構成組織を変化させ, 還元 凨の作用を受けやすくなるように毛髮構造を変化させて いると考えられる.

しかし, これら前処理の影響を受けた構造は, 自重応 力および脱膨潤応力の緩和に対しては異なった緩和挙動 を示すようである。まず，乾燥状態のウェーブ形状より， ギ酸・酢酸処理毛髪(図 3(2)-DRY) およびエタノール/ク ロロホルム処理毛髪(図3 (3)-DRY)では, ウェーブ山数は 1 山減少し, 毛髪長も伸びて未処理毛髪のウェーブ形状と 
ほとんど変わらなくなった。 それに対して, 者沸処理毛 髪(図 3(4)-DRY)では, ウェーブ毛髪長は他の前処理毛髪 と同様に長くなり未処理毛髪の毛髪長とほぼ同じになっ たが, 山数はほとんど変わらず, 結果的に未処理毛髪の それに比べ 1 山多いウェーブ形状となった.

ここで使用したいずれの前処理も毛髮より構成成分の 一部を抽出除去していることは既に述べた。 しかし，前 処理によって乾燥後のウェーブ形成に及ぼす影響は異 なっている。これは, 成分除去に伴う組織の構造変化の 違い, あるいは前処理法によって抽出作用を受ける組織 の違いが考えられる。

まず，ギ酸・酢酸およびエ夕ノール/クロロホルムによ るケラチン繊維の前処理については, これまでに多くの 研究者により研究され, 毛髪構造特に CMC 構造への影響 について議論されてきた[5-9]. A. Negri ら[6]は, 羊毛へ のギ酸処理によりコルテックス細胞間の CMC からタンパ ク質が除去されると報告している.さらにY. Nakamura[5] らは, 羊毛へのギ酸処理-酢酸処理後, 透過型電子顕微鏡 $(\mathrm{TEM})$ 観察により毛髪表面に近い部分の $\mathrm{CMC}-\delta$ 層の連続 性が失われ CMC- $\delta$ 層が細くなったことを報告している.

WET

(1)

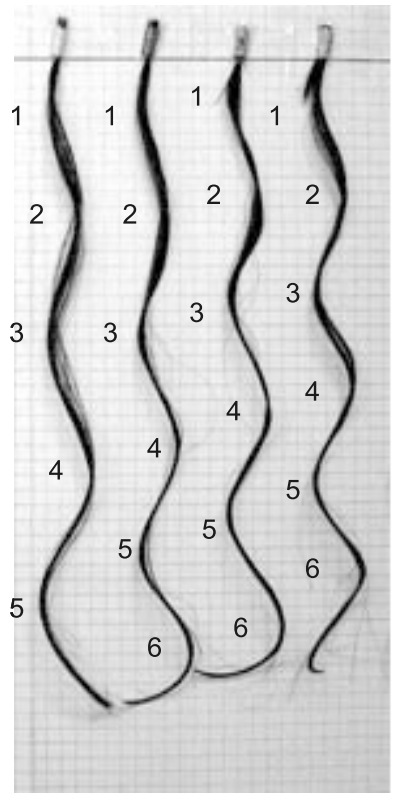

(1): Samples of untreated normal hair

(2): Samples treated with formic acid and acetic acid

(3): Samples treated with ethanol/chloroform mixture

(4): Samples treated with boiling water

Fig. 3 The effects of the extraction treatment with the difference solvents on the waving performance of normal hair fibers waved by the permanent waving process consisting in using the rod of $15 \mathrm{~mm}$ and reducing with 7\% TGA solution at $\mathrm{pH} 9.0$, RT for $15 \mathrm{~min}$, rinsing with water and oxidizing with 7\% SB solution pH 6.0, RT for 10 min. [WET : in the wet state, DRY : in the dry state.]
また, P. W. Wertz ら [7]や M. P. Mansour[8]らは, メタノー ルノクロホルム抽出によりコルテックス細胞間の遊離脂 質の除去が可能であるとしている。

ウェーブはロッド巻きで生じた初期歪みを緩和するた めに構成分子が再配列することによって形成される。こ の場合 $\mathrm{CMC}$ を構成する分子もウェーブ形状に応じて再配 列すると考えられる。したがって，これまでに報告され たギ酸・酢酸処理およびエタノール/クロロホルム処理の 作用に関する知見に従えば, 図 3 で見られた未処理毛髪 とギ酸・酢酸処理およびエタノール/クロロホルム処理毛 髪とのウェーブ形成挙動の差異は, 主に構造が変化した $\mathrm{CMC}$ が深く関係していると考えざるを得ない.すなわち, ギ酸・酢酸処理およびエ夕ノール/クロロホルム処理によ り変化した $\mathrm{CMC}$ の構造は, 還元剤の浸透が容易な構造で あり, 自重応力おょび脱膨潤応力に対して二次結合の切 断/再結合を伴う分子再配列が起こりやすい構造であると 言える.

ところで, 乾燥後の未処理毛髪とギ酸・酢酸およびエ タノールノクロロホルム処理毛髪のウェーブ形状は見かけ 上ほぼ同じと見なせる.この形状だけから判断すると, 前処理の影響はないと見ることができる.しかし, 今回 の実験から, 未処理毛髪とギ酸・酢酸あるいはエ夕ノー ル/クロロホルム処理毛髪では, 乾燥時での形状に至るま でのウェーブ形成挙動も明らかに異なっていることから， 見かけは同じ形状であっても毛髪内部の性状は異なって いることは明らかである.

一方, 煮沸処理についてであるが, 毛髪の構造変化の 観察や羊毛や他のケラチン繊維の熱変性実験によって形 態学的に検討されている. M. P. Mansour[8]らは, 煮沸処 理後の毛髮断面の TEM 観察結果より, 者沸によって キューティクル細胞やキューティクル-コルテックス細胞 間およびコルテックス細胞間の CMCに変化は見られな かったと報告している，堀内 [9]らは，羊毛についての熱 損傷に関する情報を含めたケラチン繊維の物理的化学的 変化についてまとめており, 羊毛を熱水で処理すると熱 分解により $70^{\circ} \mathrm{C}$ 以上で $\mathrm{S}-\mathrm{S}$ および $\mathrm{SH}$ 含有量が減少し, $100^{\circ} \mathrm{C}$ では構成タンパク質がポリペプチドあるいは構成ア ミノ酸として溶出するとしている.

以上のように, 煮沸処理によって易抽出成分が得られ た事実および上述の報告から, CMC 構造に対しては顕著 な変化をもたらしていないようであるが, 毛髪の全組織 がなんらかの影響を受けていると考えることができる. この影響が還元剤の浸透の増大につながり, ウェーブ山 数が未処理毛髪のそれと比べ増加したと考えられる.し かし, 煮沸処理毛髪では, 乾燥時には山数および毛髪長 の変化は見られず, CMC 組織が主に改質された処理毛髪 とは異なる挙動を示した。この挙動は, 緒言でも述べた ように, ウェーブ山数の減少挙動が非還元域の復元力の 働きによるものであることから, 煮沸処理毛髪では復元 力の働きが弱くなったためと考えられる. 


\section{3 ブリーチ処理毛髮でのウェーブ形成}

\subsection{1 ブリーチ処理と毛髮構造変化}

ブリーチ処理毛髪に対する $12 \mathrm{~mm}$ 径および $15 \mathrm{~mm}$ 径 ロッドを用いたパーマネントウェーブ処理後のウェーブ 形状を図 4 に示す。図中のウェーブは, 未処理毛髪と同 様の傾向を示したが, ウェーブ山数では, 未処理毛髪と 比べると湿乾時ともに $15 \mathrm{~mm}$ 径ロッドで 2 山, $12 \mathrm{~mm}$ 径 ロッドで 1 山多く形成されている. また乾燥後, $12 \mathrm{~mm}$ 径 のロッドではウェーブ山数が 1 山減少し, 毛髪長が大き く伸びており，15mm 径のロッドを使用したウェーブ毛髪 では, 湿乾状態での形状にほとんど変化は見られない. このことから, ブリーチ処理毛髪の場合でも，未処理毛 と同様に異なるロッド径によって形成した分子構造は, 自重応力および脱膨潤応力に対する抵抗力が異なる構造 であることが分かる.

ブリーチ処理では, 過酸化水素を用いて毛髪のメラニ ン色素を分解し脱色を行っている. しかし，ブリーチ処 理はメラニン色素の分解だけでなく, キューティクルや コルテックス構造に変化を与えていることが多く報告さ れている. H. Zahn[2]らは, ブリーチ処理によるメラニン の溶出とそれに伴うシステイン酸の増加について報告し

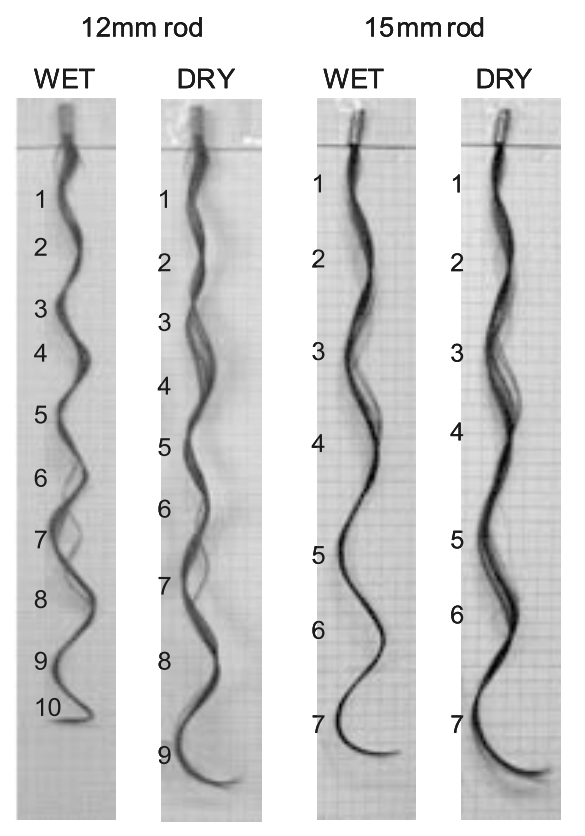

Fig. 4 The waving performance of bleached hair fibers waved by the permanent waving process consisting in using two rod types of $12 \mathrm{~mm}$ and $15 \mathrm{~mm}$ and reducing with $7 \%$ TGA solution at $\mathrm{pH} 9.0$, RT for $15 \mathrm{~min}$, rinsing with water and oxidizing with $7 \%$ SB solution $\mathrm{pH} 6.0$, RT for $10 \mathrm{~min}$.

The bleaching carried out with $6 \%$ hydrogen peroxide solution mixed with $12 \mathrm{Lv}$ lightener (DEMI, ASSORT ALLIA 12/LT) and bleach powder (DEMI, BLEACH POWDER) at RT for 30 min. [WET : in the wet state, DRY : in the dry state.]
ている.また, 川副[10]らは, ブリーチ処理毛髪ではエ ンドキューティクルに多くの空洞が観察されたとしてい る. 西田[11]らもまた, ブリーチ時間に応じて毛髪の親 水性が増すことを報告し, この親水化を過酸化水素やア ルカリによってキューティクル層の最表面に存在する F-Layer が剥離しその下層の A-Layer が最表層に出てくる ためであると推定している. 加えて, コルテックス部分 の TEM 観察では, ブリーチ 3 回処理毛においてメラニン が失われたことによる無数の空隙とそれらを結ぶ非ケラ チン組織成分 (CMC, マクロフィブリル間物質)が疎にな りつつあることを報告している．さらに金高ら[12]は， 未処理毛髪とブリーチ処理毛髪をパーマネントウェーブ 還元剂で浸漬処理した結果, それぞれ異なるタンパク質 が検出されたと報告している。 そして, それらのタンパ ク質は, 未処理毛髪の場合ではシスチンを含まずコラー ゲン類似の非ケラチンタンパク質であり, 還元剤により 膨潤軟化したコルテックス細胞間 CMC 域から溶出した成 分であるとした，それに対して，ブリーチ処理毛髪では コルテックス細胞の硫黄含有率の高い非晶性, 低分子量 のケラチンから成るマトリックスの一部が溶出されてい たことから, コルテックス細胞内を埋めるマトリックス 部分からも溶出が起こっていると推定している.

これらの報告より, ブリーチ処理ではメラニン色素の 分解とともに起こるエンドキューティクル層での空洞化 やコルテックス細胞層内のメラニン色素充填組織成分の 流出に伴う構造の乱れが, 還元処理溶液が浸透しやすく なった原因であると考えられる.すなわち, ブリーチ処 理毛髪では, 同一時間処理での還元剤の拡散域が増大す るものと考えられ, この増大が未処理毛髪に比べて増加 したウェーブ山数に対応すると考えられる．このことは， 緒言で述べたように還元域ではロッド巻きにより生じた 歪みが緩和されており, ウェーブ山数が還元域での歪み 緩和量に依存するとした考えからも支持される。

\subsection{2 ウェーブ形状に及ぼす前処理の影響}

図 5 はブリーチ処理毛髪をギ酸・酢酸処理, エ夕ノー ル/クロロホルム処理および煮沸処理を行った前処理毛髪 でのパーマネントウェーブ処理後のウェーブ毛髪の形状 を示したものである.

まず，湿潤状態の各ウェーブ形状を比較すると，ブリー 于処理毛髪に比べ前処理毛髪のウェーブ毛髪長は短くな るが, ウェーブ山数ではギ酸・酢酸処理毛髪(図 5(2)WET) とエタノール/クロロホルム処理毛髪(図 5(3)-WET) は 1 山減り, 煮沸処理毛髪 (図 5(4)-WET) では山数は同数 であった。 上述したように前処理は還元剤の浸透経路に 関する毛髪構成組織を変化させ, 還元剤の作用を受けや すくなるように毛髪構造を変化させていると考えられた。 ところが, ギ酸・酢酸処理毛髪とエ夕ノールノクロホル ム処理毛髪ではウェーブ山数は減少した.この現象は還 元剤の作用はより進行していると考えられることから, これらの前処理によって自重応力に対する抵抗力が小さ 
WET

(1)

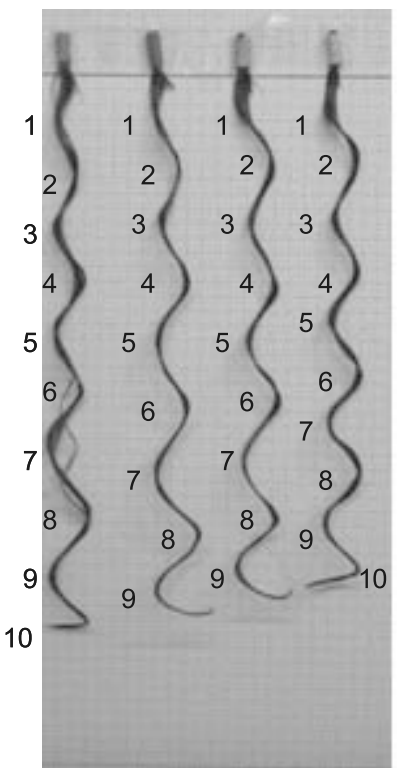

DRY
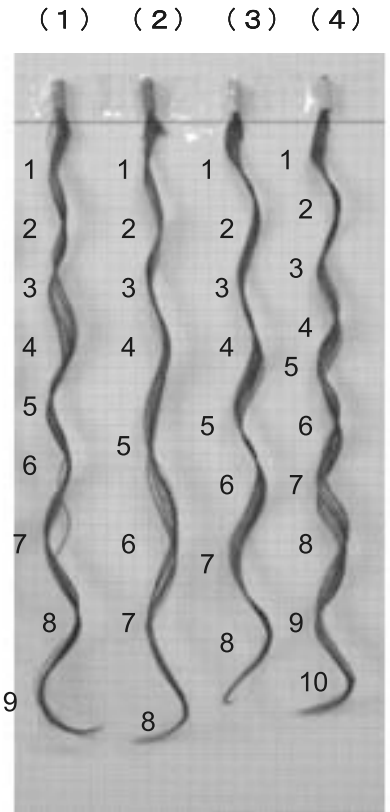

(1): Samples of untreated bleached hair

(2): Samples treated with formic acid and acetic acid

(3): Samples treated with ethanol/chloroform mixture

(4): Samples treated with boiling water

Fig. 5 The effects of the extraction treatment with the difference solvents on the waving performance of bleached hair fibers waved by the permanent waving process consisting in using the rod of $12 \mathrm{~mm}$ and reducing with 7\% TGA solution at $\mathrm{pH}$ 9.0, RT for $15 \mathrm{~min}$, rinsing with water and oxidizing with $7 \%$ SB solution $\mathrm{pH} 6.0$, RT for $10 \mathrm{~min}$. [WET : in the wet state, DRY : in the dry state.]

い構造に変化したと考えられる。それに対して，煮沸処 理毛髪の構造は抵抗力を保持した構造であると考えられ る. 既に述べたように, ブリーチ処理では, メラニン色 素の分解とともにメラニン色素充填組織成分の流出が起 こると報告されている[11]，すなわち，少なくともメラ ニンが存在する CMC 領域がブリーチ処理で改質されてい ると考えて差し支えないものと思われる．したがって， ギ酸・酢酸処理およびエ夕ノール/クロロホルム処理に よって, ブリーチ処理で構造が変化している $\mathrm{CMC}$ がさら に構造変化し, 自重応力に対するウェーブ保持力の弱い CMC となったものと考えられる.

次に, 乾燥状態において前処理の影響を未処理毛髪と ブリーチ処理毛髪で異なる点に着目する。ブリーチ処理 毛髪とギ酸・酢酸処理およびエ夕ノール/クロロホルム処 理毛髪のいずれも湿潤時よりウェーブ山数は一山減少し ている.このことから, 乾燥時に生じる脱膨潤応力に対 するギ酸・酢酸およびエ夕ノール/クロロホルム処理毛髪 の抵抗力はブリーチ毛髪のそれと大差ないものと見なす ことができる.

一方, 煮沸処理の影響であるが, 毛髪のウェーブ形状
変化の挙動がブリーチ処理毛髪のそれとほとんど変わら なかったことから, 煮沸処理による構造への影響はブリー 于処理毛髪においても未処理毛髪で見られた効果とほぼ 同じであると考えることができる.

\section{4. 結 論}

本研究では, 未処理毛髪やブリーチ処理毛髪に前処理 を行い, パーマネントウェーブ処理を行うことで形成さ れるウェーブの形状を比較することから, 毛髪前処理の ウェーブ形成におよぼす効果について検討を行った.

まず，未処理毛髪においてギ酸・酢酸処理毛髪，エ夕 ノール/クロロホルム処理毛髪, 煮沸処理毛髪におけるパー マネントウェーブ形状は, 自重応力および脱膨潤応力の 緩和に対して異なった緩和メカニズムを示した。この違 いは, ギ酸・酢酸処理およびエ夕ノール/クロロホルム処 理により改質される $\mathrm{CMC}$ が深く関係していると結論付け た.すなわち, ギ酸・酢酸処理およびエ夕ノール/クロロ ホルム処理により変化した CMC 構造は, 還元剂の浸透が 容易な構造であり, 自重応力および脱膨潤応力に対して 二次結合の切断/再結合を伴う分子再配列が起こり易い構 造となったと言える.

一方，ブリーチ処理毛髪では，ブリーチ処理により顕 著に影響を受けていると考えられる細胞組織での還元量 の増大が, ウェーブ山数を増加させる原因であることが 確かめられた。ささらに，ギ酸・酢酸処理およびエ夕ノー ルノロロホルム処理による改質にともない毛髪のウェー ブ保持力が低下したことから， CMC 域がウェーブ形状の 保持に重要な役割を果たしていることが示唆された.

以上，これまで毛髪重量の数\%を占めるのみであるため， ウェーブ形成における役割が見落とされていた CMC 域が ウェーブ形成およびウェーブ保持力に関わっていること を明らかにできたことは，毛髪構成組織それぞれの役割 を含めたパーマネントウェーブ形成機構の解明への端緒 となるのではと期待される.

\section{文 献}

1. C. R. Robbins, "Chemical and Physical Behavior of Human Hair" 4th Ed. Fragrance Journal Ltd., Tokyo, PP. 25-56 (2006).

2. H. Zahn, S.Hilterhaus, and A.Strüßmann, J.Soc. Cosmet. Chem., 37, 159-175 (1986).

3. F. J. Wortmann, N.Kure, J. Soc. Cosmet. Chem., 45, 149158 (1994).

4. C. R. Robbins, "Chemical and Physical Behavior of Human Hair" 4th Ed. Fragrance Journal Ltd., Tokyo, PP.109 (2006).

5. Y. Nakamura, K. Kosaka, M. Tada, K. Hirota, and S. Kunugi, Proceedings of The 7th International Wool 
Textile Research Conference, Vol. I, 171-180 (1985).

6. A. Negri, D. A. Rankin, W. G. Nelson, and D. E. Rivett, Textile Res.J., 66, 491-495 (1996).

7. P.W.Wertz and D. T. Downing, Comp. Biochem. Physiol., Vol. 92B, No.4, 759-761 (1989).

8. M. P. Mansour and L. N. Jones, Textile Res.J, 59, 530-535 (1989).
9. T. Horiuchi, J. Soc. Cosmet. Chem., Vol.14, No.2, 105115(1980).

10. T. Kawasoe, T. Fujiyama, and H. Shimizu, Japanese Cosmetic Science Society, Vol.31, No.4, 273-279(2007).

11. Y. Nishida, M. Hosokawa, T. Ito, M. Aono, Fragrance Journal, 8, 33-41(2002).

12. S. Kanetaka, K. Miyata, and Y. Nakamura, J. Soc. Cosmet. Chem., Vol.24, No.1, 5-12(1990). 